\title{
Antitumor Effects and Related Mechanisms of Penicitrinine A, a Novel Alkaloid with a Unique Spiro Skeleton from the Marine Fungus Penicillium citrinum
}

\author{
Qin-Ying Liu ${ }^{1,2}$, Tong Zhou ${ }^{1}$, Yang-Yang Zhao ${ }^{1}$, Li Chen ${ }^{1, *}$, Mei-Wei Gong ${ }^{1}$, Qi-Wen Xia ${ }^{1}$, \\ Min-Gang Ying ${ }^{2}$, Qiu-Hong Zheng ${ }^{2, *}$ and Qi-Qing Zhang ${ }^{1,3, *}$
}

1 Institute of Biomedical and Pharmaceutical Technology, Fuzhou University, Fuzhou 350002, China; E-Mails: liuqinyingbio@163.com (Q.-Y.L.); vickychou90220@163.com (T.Z.); zhaoyangyang0929@163.com (Y.-Y.Z.); 742946642@qq.com (M.-W.G.); xiaqiwen0917@163.com (Q.-W.X.)

2 Fujian Provincial Key Laboratory of Tumor Biotherapy, Fujian Provincial Tumor Hospital, Fuzhou 350014, China; E-Mail: yingmg@163.com

3 Institute of Biomedical Engineering, Chinese Academy of Medical Science, Peking Union Medical College, Tianjin 300192, China

* Authors to whom correspondence should be addressed; E-Mails: ibptcl@fzu.edu.cn (L.C.); zqh2858@foxmail.com (Q.-H.Z.); zhangqq@ fzu.edu.cn (Q.-Q.Z.); Tel.: +86-591-83725260 (L.C. \& Q.-Q.Z.); +86-591-83660063 (Q.-H.Z.); Fax: +86-591-83725260 (L.C. \& Q.-Q.Z.); +86-591-83677110 (Q.-H.Z.).

Academic Editor: Orazio Taglialatela-Scafati

Received: 22 May 2015 / Accepted: 1 July 2015 / Published: 31 July 2015

\begin{abstract}
Penicitrinine A, a novel alkaloid with a unique spiro skeleton, was isolated from a marine-derived fungus Penicillium citrinum. In this study, the isolation, structure and biosynthetic pathway elucidation of the new compound were described. This new compound showed anti-proliferative activity on multiple tumor types. Among them, the human malignant melanoma cell A-375 was confirmed to be the most sensitive. Morphologic evaluation, apoptosis rate analysis, Western blot and real-time quantitative PCR (RT-qPCR) results showed penicitrinine A could significantly induce A-375 cell apoptosis by decreasing the expression of $\mathrm{Bcl}-2$ and increasing the expression of Bax. Moreover, we investigated the anti-metastatic effects of penicitrinine A in A-375 cells by wound healing assay, trans-well assay, Western blot and RT-qPCR. The results showed penicitrinine A significantly suppressed metastatic activity of A-375 cells by regulating the
\end{abstract}


expression of MMP-9 and its specific inhibitor TIMP-1. These findings suggested that penicitrinine A might serve as a potential antitumor agent, which could inhibit the proliferation and metastasis of tumor cells.

Keywords: penicitrinine A; marine-derived fungus; human malignant melanoma cell A-375; anticancer activity; apoptosis; anti-metastatic

\section{Introduction}

Malignant melanoma is one of the few cancers that have displayed an increasing incidence and, more importantly, a steady mortality rate over the past decade [1,2]. Even if surgery represents the cure in the early phase of disease, the prognosis in the metastatic phase remains very poor. Recently, immune checkpoint blockade with monoclonal antibodies directed at the inhibitory immune receptors CTLA-4 and PD-1 has emerged as a successful treatment approach for patients with advanced melanoma [3]. However, chemotherapy remains an essential treatment option [4]. Moreover, recurrence/metastasis is the major cause of death in patients with malignant melanoma cancer. Therefore, novel potent drugs, especially anti-metastasis drugs, would be urgently needed for the treatment of refractory or relapsing melanoma cancer patients [5].

Natural product compounds have substantial structural diversity and frequently afford new mechanisms of biological activity [6]. As a result, it is believed that a rich source of anticancer drug candidates could be obtained from natural products [5]. Almost all of the current natural anticancer drugs were either isolated or derived from plants and terrestrial microorganisms. However, after 50 years of intensive screening from plants and terrestrial microbes, the pace of natural products' discovery and development with a unique scaffold has dramatically declined over the last two decades [7]. Recent trends in drug discovery emphasize that marine microorganisms are a potentially productive source of novel secondary metabolites and have great potential to increase the number of marine natural products in clinical trials [8]. The oceans are highly complex environments and house a diverse assemblage of microbes that occur in environments with extreme variations in pressure, salinity, and temperature [9]. Marine microorganisms have attracted great attention since they have developed unique metabolic and physiological capabilities that not only ensure survival in extreme habitats but also offer the potential to produce compounds with antitumor and other interesting pharmacological activities that would not be observed in terrestrial microorganisms [10-12]. Recently, several synthetic analogues with a promising anti-proliferative activity are reported [13-18].

In our study, more than 300 microbial strains isolated from sediment samples collected from the Min River estuary in China were screened for cytotoxicity against cancer cells. Among them, a fungal strain identified as Penicillium citrinum exhibited significant cytotoxic activity. We investigated the secondary metabolites of this fungus and obtained a novel alkaloid, penicitrinine A with a unique spiro skeleton. It is the first metabolite biosynthesized from citrinin and tetramic acid derivatives in nature. The chemical structure of this compound was determined according to 1D, 2D NMR and HRESIMS spectroscopic data. We investigated the cytotoxic effect of penicitrinine A on human melanoma A-375 cells and the detail mechanism in its regulation of apoptosis and metastasis. The results confirmed that 
penicitrinine A exhibited potent pro-apoptosis and anti-metastatic activity in human melanoma A-375 cell line, indicating that it might serve as a potential antitumor lead compound.

\section{Results and Discussion}

\subsection{Structure Elucidation}

Penicitrinine A was obtained as yellow oil and analyzed to have the molecular formula $\mathrm{C}_{28} \mathrm{H}_{39} \mathrm{NO}_{6}$ through negative HRESIMS ( $m / z$ : $484.2711[\mathrm{M}-\mathrm{H}]^{-}$, Calcd for $\mathrm{C}_{28} \mathrm{H}_{38} \mathrm{NO}_{6}$ : 484.2705). Its NMR data (Table 1), combined with DEPT and HMQC spectrum analyses, revealed twenty-eight carbon signals, including seven methyls, five methylenes, six methines, and ten quaternary carbons. The 1D-NMR data of penicitrinine A mixed data of penicitrinol $C$ [19] with that of penicillenol $A_{1}$ [20], except for an obviously downfield shift of C-5' (from $68.7 \mathrm{CH}$ to $94.0 \mathrm{qC}$ ) [20], an obviously upfield shift of C-6' (from 66.6 $\mathrm{CH}$ to $35.7 \mathrm{CH}$ ) [20], and the absence of an acetonyl group [19]. The COSY correlations (Figure 1) of H-6' with H-1 and H-7', and the HMBC correlations (Figure 2) from H-6' to C-4', C-5', and $\mathrm{C}-9$, and from $\mathrm{H}-7^{\prime}$ to $\mathrm{C}-5^{\prime}$ suggested that two monomers were finally connected through $\mathrm{C}-1$ and $\mathrm{C}-6^{\prime}$ as well as $8-\mathrm{OH}$ and $\mathrm{C}-5^{\prime}$. Furthermore, the relative configurations of penicitrinine A were revealed through the NOESY experiment. The NOESY correlations (Figure 2) of H-1 with H-7' and H-11, H-11 with $\mathrm{H}-4, \mathrm{H}-3$ with $\mathrm{H}-12$, and $\mathrm{H}-6^{\prime}$ with $\mathrm{H}-17^{\prime}$ indicating that $\mathrm{H}-1, \mathrm{H}-4,11-\mathrm{CH}_{3}$ and $7^{\prime}-\mathrm{CH}_{3}$ were on the same side, whereas $\mathrm{H}-3,12-\mathrm{CH}_{3}, \mathrm{H}-6^{\prime}$ and $\mathrm{N}-\mathrm{CH}_{3}$ were on the opposite side. Therefore, the structure of penicitrinine A was elucidated as shown (Figure 2).

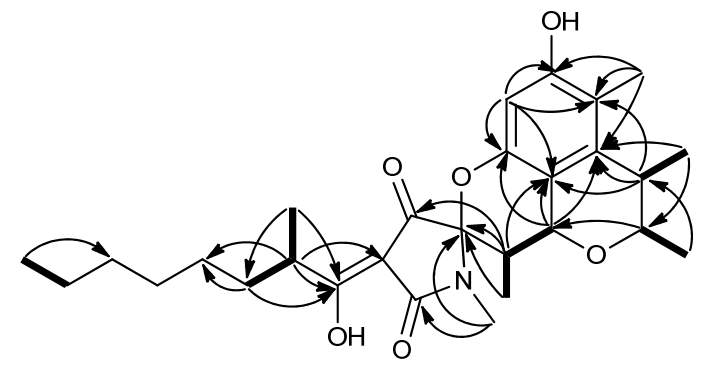

- COSY

$\mathrm{HMBC}$
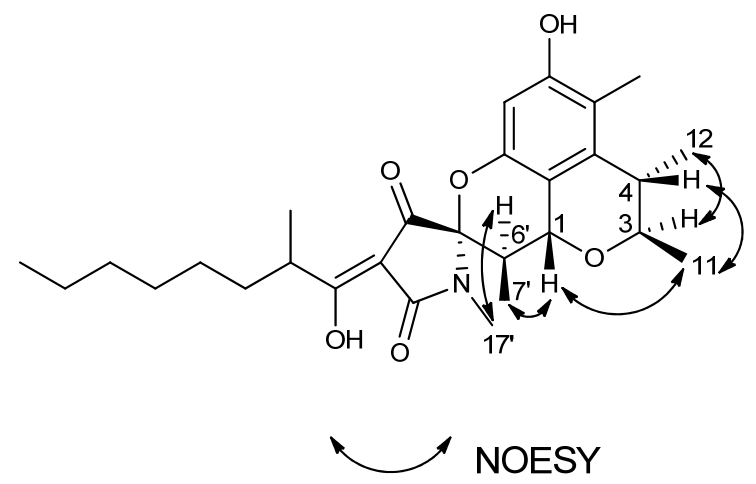

Figure 1. Key COSY, HMBC and NOESY correlations of penicitrinine A.

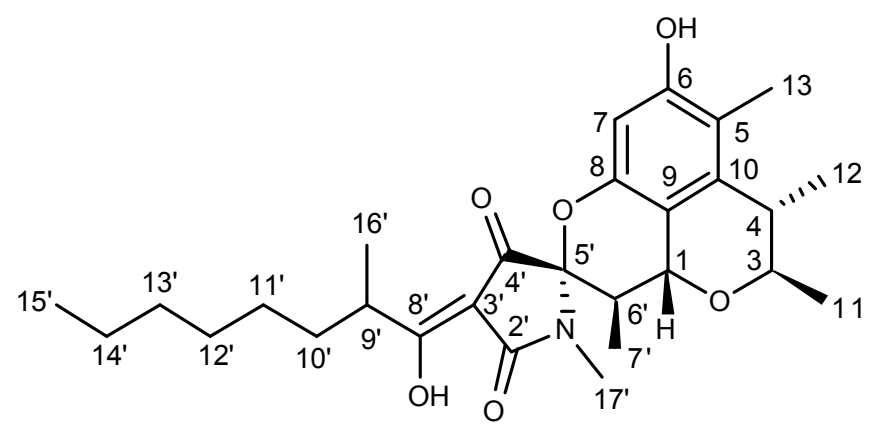

Figure 2. Chemical structure of penicitrinine A. 
Table 1. $500 \mathrm{MHz}{ }^{1} \mathrm{H}$ and $125 \mathrm{MHz}{ }^{13} \mathrm{C}-\mathrm{NMR}$ data for penicitrinine $\mathrm{A}$ (in $\mathrm{CDCl}_{3}$ ).

\begin{tabular}{|c|c|c|}
\hline Position & $\delta_{\mathrm{H}}(J$ in $\mathrm{Hz})$ & $\boldsymbol{\delta}_{\mathbf{C}}$ \\
\hline 1 & $5.03(1 \mathrm{H}, \mathrm{d}, 11.0)$ & $62.9 \mathrm{CH}$ \\
\hline 3 & $4.14(1 \mathrm{H}, \mathrm{q}, 6.8)$ & $75.1 \mathrm{CH}$ \\
\hline 4 & $2.62(1 \mathrm{H}, \mathrm{q}, 6.8)$ & $34.8 \mathrm{CH}$ \\
\hline 5 & & $115.3 \mathrm{qC}$ \\
\hline 6 & & $154.2 \mathrm{qC}$ \\
\hline 7 & $6.08(1 \mathrm{H}, \mathrm{s})$ & $100.3 \mathrm{CH}$ \\
\hline 8 & & $149.2 \mathrm{qC}$ \\
\hline 9 & & $111.4 \mathrm{qC}$ \\
\hline 10 & & $136.9 \mathrm{qC}$ \\
\hline 11 & $1.40(3 \mathrm{H}, \mathrm{d}, 6.8)$ & $18.7 \mathrm{CH}_{3}$ \\
\hline 12 & $1.21(3 \mathrm{H}, \mathrm{d}, 6.8)$ & $22.4 \mathrm{CH}_{3}$ \\
\hline 13 & $2.05(3 \mathrm{H}, \mathrm{s})$ & $10.1 \mathrm{CH}_{3}$ \\
\hline $2^{\prime}$ & & $173.9 \mathrm{qC}$ \\
\hline $3^{\prime}$ & & $99.9 \mathrm{qC}$ \\
\hline $4^{\prime}$ & & $191.4 \mathrm{qC}$ \\
\hline $5^{\prime}$ & & $94.0 \mathrm{qC}$ \\
\hline $6^{\prime}$ & $2.29(1 \mathrm{H}, \mathrm{dq}, 11.0,6.8)$ & $35.7 \mathrm{CH}$ \\
\hline $7^{\prime}$ & $0.99(3 \mathrm{H}, \mathrm{d}, 6.8)$ & $10.6 \mathrm{CH}_{3}$ \\
\hline $8^{\prime}$ & & $192.3 \mathrm{qC}$ \\
\hline $9^{\prime}$ & $3.59(1 \mathrm{H}, \mathrm{m})$ & $36.2 \mathrm{CH}$ \\
\hline $10^{\prime}$ & $\begin{array}{l}1.69(1 \mathrm{H}, \mathrm{m}) \\
1.47(1 \mathrm{H}, \mathrm{m})\end{array}$ & $34.0 \mathrm{CH}_{2}$ \\
\hline $11^{\prime}$ & $1.24 \sim 1.37(2 \mathrm{H}, \mathrm{m})$ & $27.3 \mathrm{CH}_{2}$ \\
\hline $12^{\prime}$ & $1.24 \sim 1.37(2 \mathrm{H}, \mathrm{m})$ & $29.3 \mathrm{CH}_{2}$ \\
\hline $13^{\prime}$ & $1.24 \sim 1.37(2 \mathrm{H}, \mathrm{m})$ & $22.7 \mathrm{CH}_{2}$ \\
\hline $14^{\prime}$ & $1.24 \sim 1.37(2 \mathrm{H}, \mathrm{m})$ & $31.8 \mathrm{CH}_{2}$ \\
\hline $15^{\prime}$ & $0.87(3 \mathrm{H}, \mathrm{t}, 7.0)$ & $14.2 \mathrm{CH}_{3}$ \\
\hline $16^{\prime}$ & $1.17(3 \mathrm{H}, \mathrm{d}, 6.9)$ & $17.3 \mathrm{CH}_{3}$ \\
\hline $17^{\prime}$ & $2.90(3 \mathrm{H}, \mathrm{s})$ & $23.1 \mathrm{CH}_{3}$ \\
\hline
\end{tabular}

\subsection{Biosynthesis of Penicitrinine A}

Our previous chemical investigation of this strain reported the isolation of sixteen citrinin derivatives [19,21,22] and four tetramic acid derivatives [22], among which citrinin and penicillenol $\mathrm{B}_{1}$ seemed to be the biosynthetic precursors of penicitrinine A. During this biosynthesis process, the Diels-Alder reaction was involved in these two compounds. To clearly explain the biogenetic origin of penicitrinine A, a plausible biosynthetic pathway is proposed in Figure 3. 


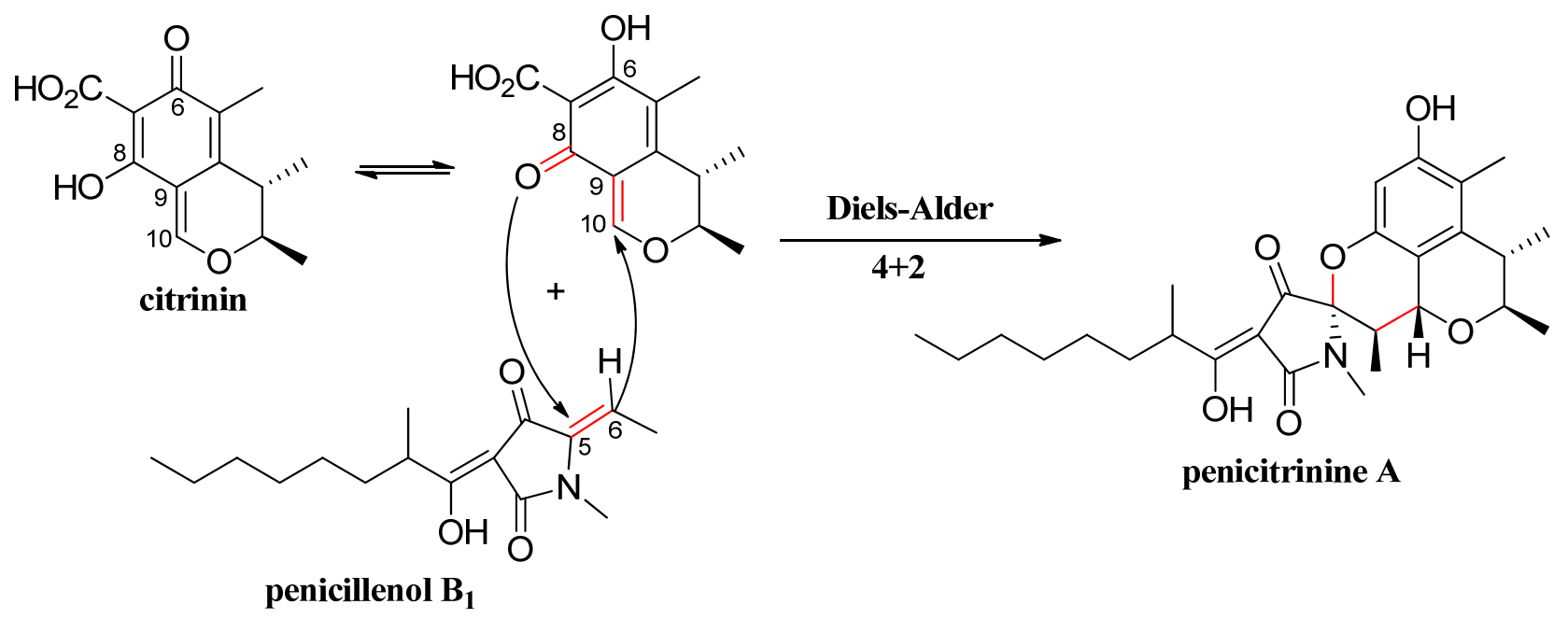

Figure 3. Plausible biosynthetic pathway of penicitrinine A.

\subsection{Penicitrinine A Inhibits the Proliferation of Multiple Tumor Types}

The cytotoxic effect of penicitrinine A was evaluated in a panel of twenty-three cancer cell lines derived from ten different types of tumors. As shown in Figure 4, different tumor cell lines had different levels of proliferation inhibition after treated with gradient concentrations of penicitrinine A for $48 \mathrm{~h}$. The most sensitive cell lines were malignant melanoma cell line A-375, lung cancer cell line SPC-A1 and stomach cancer cell line HGC-27 with $\mathrm{IC}_{50}$ values of $20.12 \mu \mathrm{M}, 28.67 \mu \mathrm{M}$ and $29.49 \mu \mathrm{M}$, respectively (Table 2 ). Since the A-375 cell line was the most sensitive, we finally chose it as the target cell line for further study.

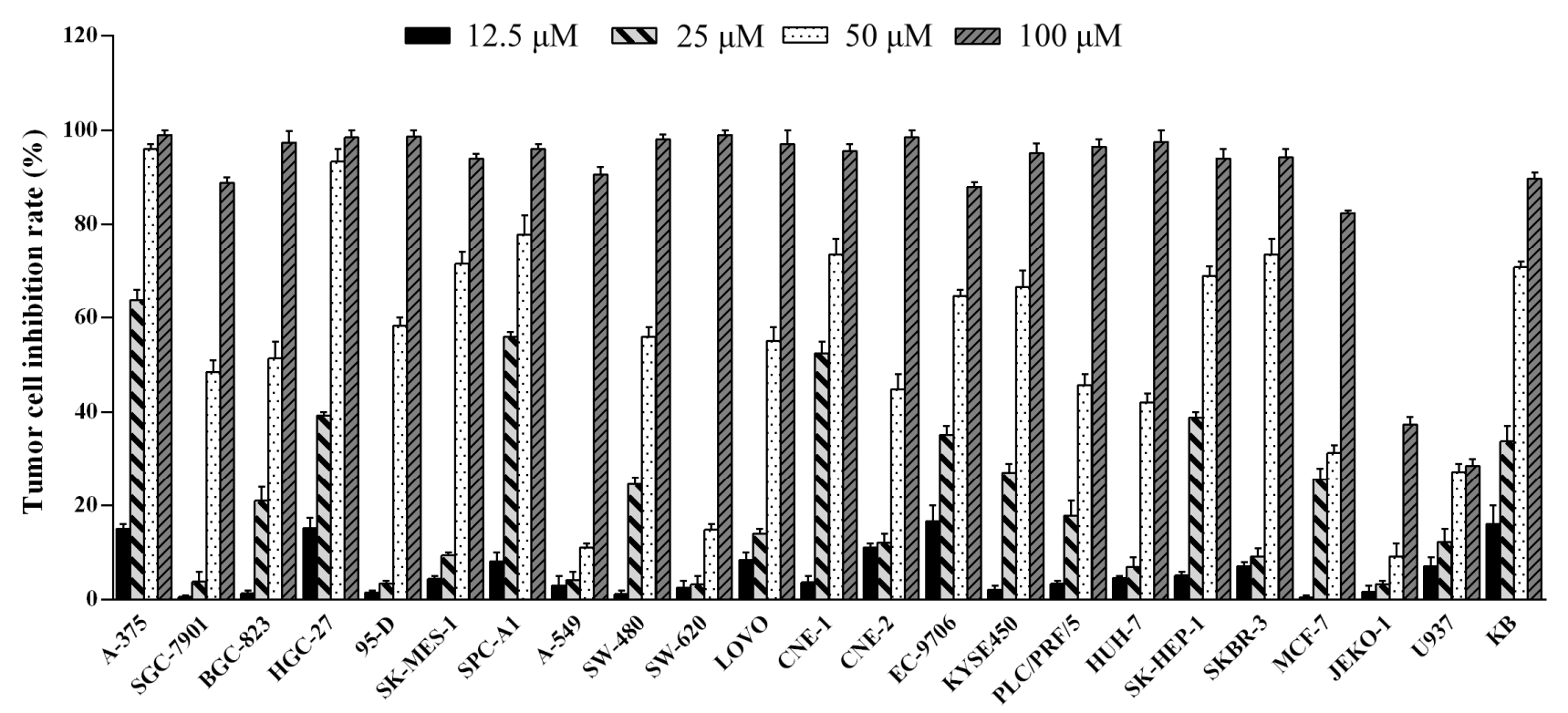

Figure 4. Tumor cell-growth inhibitory activity of penicitrinine A. Twenty-three tumor cell lines were treated with penicitrinine $\mathrm{A}$ for $48 \mathrm{~h}$ at concentrations from 12.5 to $100 \mu \mathrm{M}$. The data are presented as means $\pm \mathrm{SD}$ from five independent experiments. 
Table 2. Inhibition of tumor cell-growth activity of penicitrinine A.

\begin{tabular}{|c|c|c|c|c|c|}
\hline Human Cancer Type & Cell Line & $\mathrm{IC}_{50}(\mu \mathrm{M})$ & Human Cancer Type & Cell Line & $\mathrm{IC}_{50}(\boldsymbol{\mu M})$ \\
\hline \multirow{3}{*}{ Stomach cancer } & SGC-7901 & $>50$ & \multirow{3}{*}{ Liver cancer } & $\mathrm{PLC} / \mathrm{PRF} / 5$ & 46.13 \\
\hline & BGC-823 & 44.58 & & Huh-7 & 49.87 \\
\hline & HGC-27 & 29.49 & & SK-HEP-1 & 33.20 \\
\hline \multirow{4}{*}{ Lung cancer } & $95-\mathrm{D}$ & 47.50 & \multirow{2}{*}{ Nasopharynx cancer } & CNE-1 & 31.76 \\
\hline & SK-MES-1 & 42.40 & & CNE-2 & 45.17 \\
\hline & SPC-A1 & 28.67 & \multirow{2}{*}{ Esophagus cancer } & EC-9706 & 36.14 \\
\hline & A-549 & $>50$ & & KYSE450 & 38.89 \\
\hline \multirow{3}{*}{ Colon cancer } & SW-480 & 41.59 & \multirow{2}{*}{ Breast cancer } & SKBR-3 & 41.88 \\
\hline & SW-620 & $>50$ & & MCF-7 & $>50$ \\
\hline & LOVO & 42.33 & \multirow{2}{*}{ Lymphoma cancer } & Jeko-1 & $>50$ \\
\hline Malignant melanoma & A-375 & 20.12 & & U937 & $>50$ \\
\hline Oral epidermoid carcinoma & KB & 35.25 & & & \\
\hline
\end{tabular}

\subsection{Penicitrinine A Inhibits the Proliferation of A-375 Malignant Melanoma Cells}

In order to accurately characterize anti-proliferative potential of penicitrinine A in A-375 cells, we developed an RTCA assay to determine alive cell number. The effect of the first-line chemotherapy drug 5-Fu was also tested as a positive control on A-375 cells. The results showed that the IC 50 of A-375 with penicitrinine A treatment for $24 \mathrm{~h}, 48 \mathrm{~h}$ and $72 \mathrm{~h}$ was $30.88 \mu \mathrm{M}, 12.78 \mu \mathrm{M}$ and $7.06 \mu \mathrm{M}$, respectively, while the $\mathrm{IC}_{50}$ with 5 -Fu treatment for $24 \mathrm{~h}, 48 \mathrm{~h}$ and $72 \mathrm{~h}$ was $134.86 \mu \mathrm{M}, 65.96 \mu \mathrm{M}$ and $35.23 \mu \mathrm{M}$, respectively (Figure 5), revealing that penicitrinine A inhibits A-375 cells growth in a dose- and time-dependent manner and has more potent anticancer activity than 5-Fu.

\subsection{Penicitrinine A Induces Significant Apoptotic Morphological Changes in A-375 Cells}

To determine whether the growth inhibitory activity of penicitrinine A was related to the induction of apoptosis, we further examined the changes in cell morphology after exposure to penicitrinine A. As shown in Figure 6, $24 \mathrm{~h}$ after exposure to $5 \mu \mathrm{M}, 10 \mu \mathrm{M}$ and $20 \mu \mathrm{M}$ of penicitrinine A, A-375 cells began to show cell shrinkage, rounding and fragmentation, thus taking on the typical appearance of apoptotic cells when compared to untreated cells. We also analyzed cell morphology changes by Hoechst 33258 and $\mathrm{AO} / \mathrm{EB}$ staining, and the results showed penicitrinine A-treated cells exhibited chromatin condensation and nuclear fragmentation, which were indicative of apoptosis. 

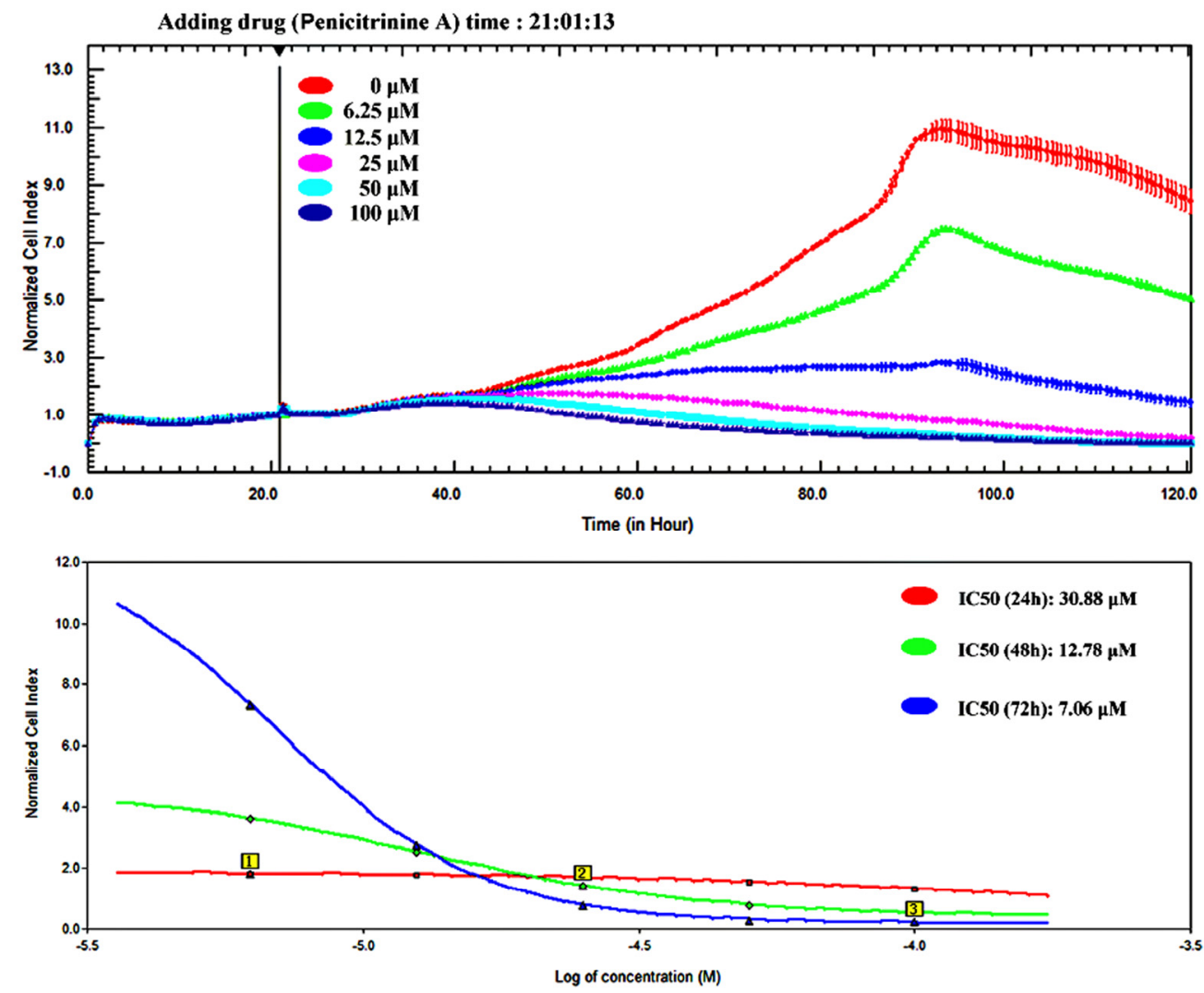

B
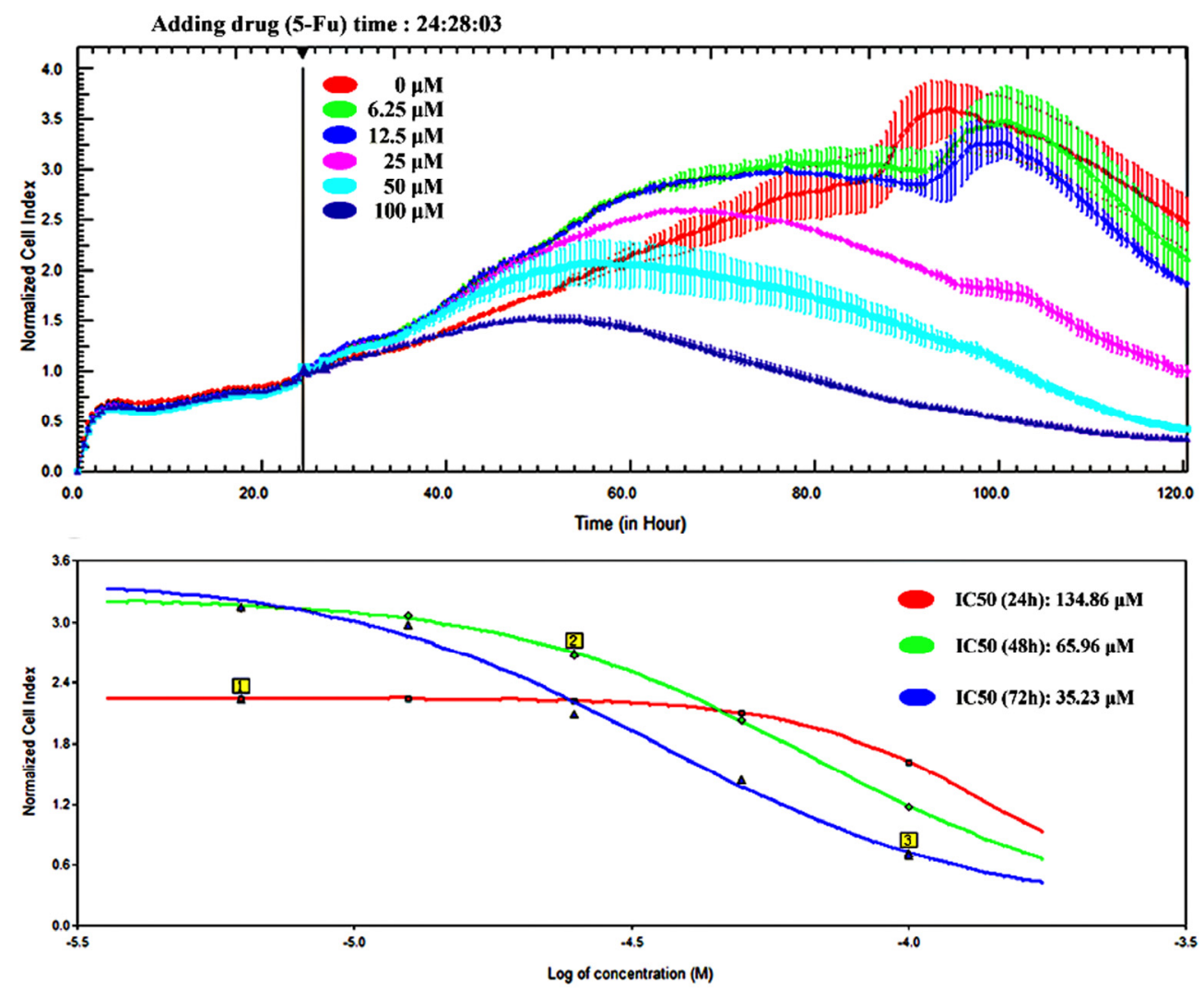

Figure 5. The viability of A-375 cells treated with penicitrinine A (A) or 5-Fu (B) was determined by RTCA assay. 


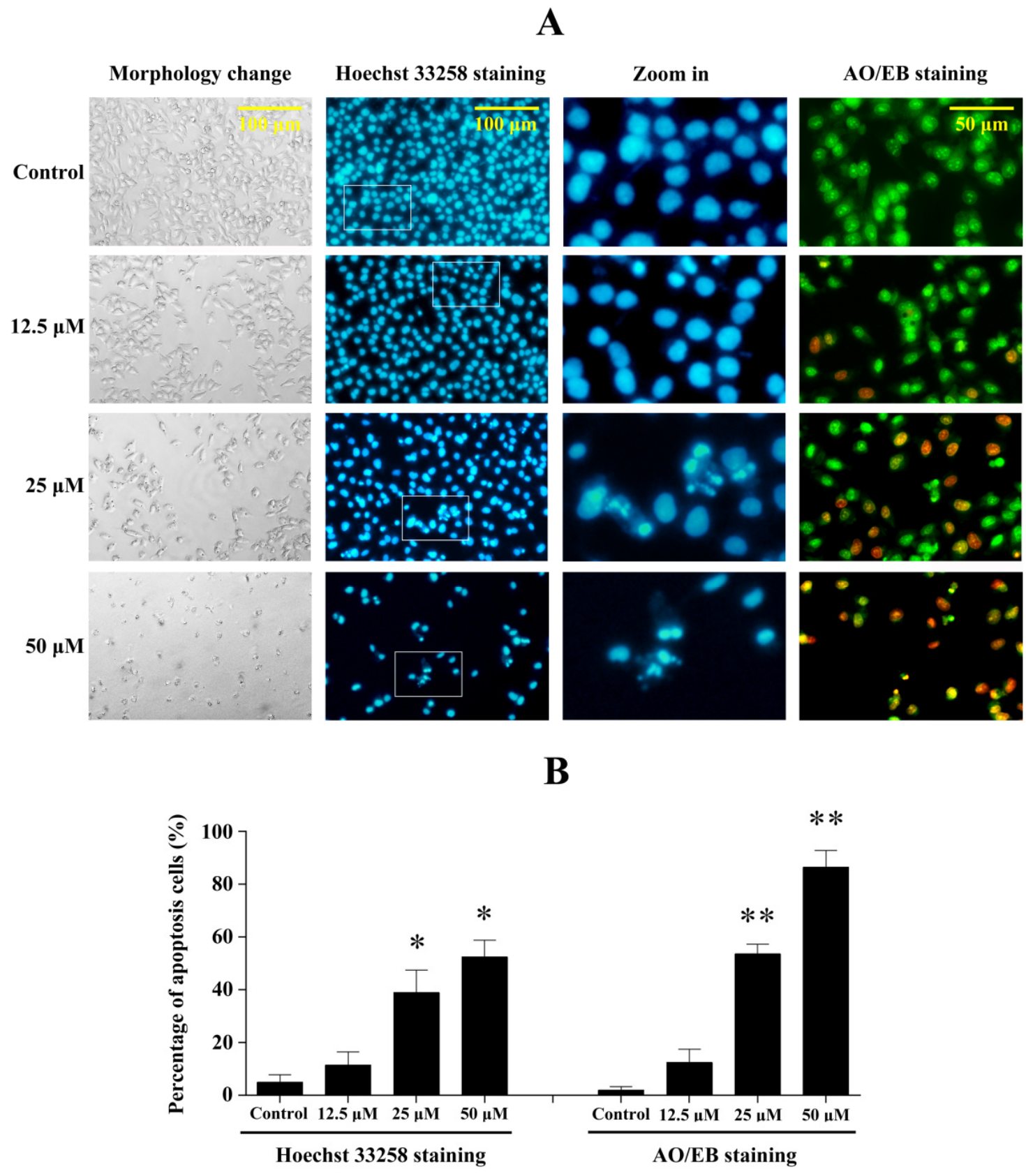

Figure 6. Penicitrinine A induced significant apoptotic morphological changes. (A) After exposed to 12.5, 25 and $50 \mu \mathrm{M}$ penicitrinine A for $24 \mathrm{~h}$, A-375 cells were stained by Hoeschest 33258 or AO/EB. Photos were taken under an inverted fluorescence microscope; (B) Quantification of the proportion of apoptotic cells detected by Hoechst 33258 staining and $\mathrm{AO} / \mathrm{EB}$ staining. The values (means $\pm \mathrm{SD}, n=3$ ) differed significantly ( $* p<0.05$; ** $p<0.01)$. The third column in Figure A was amplified from the second column for ten fold.

\subsection{Penicitrinine A Induces Apoptosis in A-375 Cells}

In order to determine the apoptotic cell death in A-375 cells induced by penicitrinine A, Annexin-V/PI double staining was performed. The results showed that apoptosis rates of A-375 cells changed from $45.80 \%, 55.58 \%$ to $91.36 \%$ when treated with $12.5 \mu \mathrm{M}, 25 \mu \mathrm{M}$ and $50 \mu \mathrm{M}$ of 
penicitrinine A (Figure 7). However, the apoptosis rates only changed from $24.50 \%, 36.83 \%$ to $55.54 \%$ when treated with $50 \mu \mathrm{M}, 100 \mu \mathrm{M}$ and $200 \mu \mathrm{M}$ of 5-Fu (Figure 7). The above results demonstrated that penicitrinine A could induce apoptosis much more effectively than $5-\mathrm{Fu}$ in a dose-dependent manner.

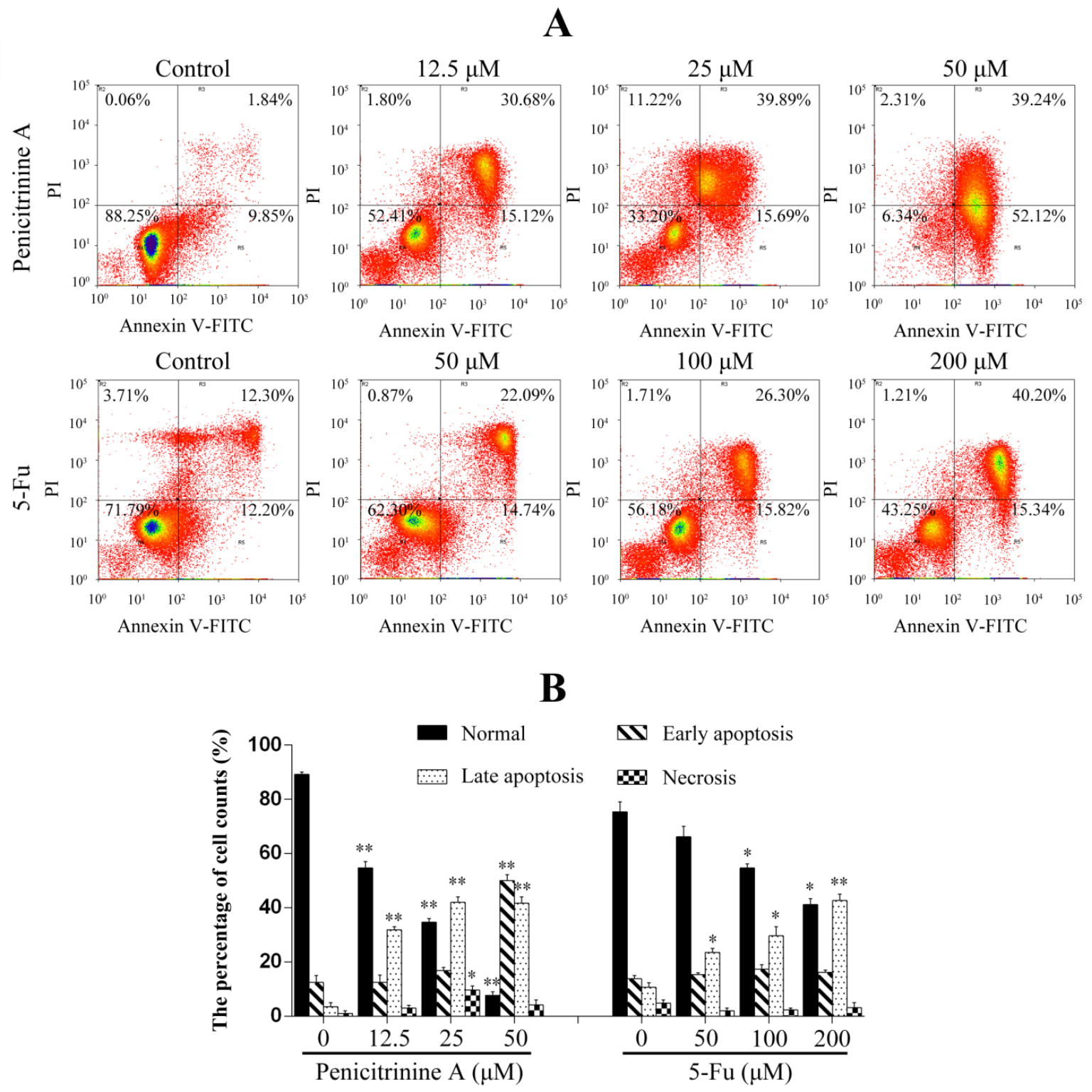

Figure 7. Penicitrinine A induced A-375 cells apoptosis. (A) A-375 cells were treated with penicitrinine $\mathrm{A}(12.5 \mu \mathrm{M}, 25 \mu \mathrm{M}$ and $50 \mu \mathrm{M})$ for $24 \mathrm{~h}$, stained by annexin-V/PI and analyzed by flow cytometry, $5-\mathrm{Fu}(50 \mu \mathrm{M}, 100 \mu \mathrm{M}$ and $200 \mu \mathrm{M})$ as a positive control; (B) Densitometry of cell counts. The values (means $\pm \mathrm{SD}, n=3$ ) differed significantly $(* p<0.05 ; * * p<0.01)$.

\subsection{Penicitrinine A Modulates Apoptosis -Related mRNA and Protein in A-375 Cells}

We next examined the protein and mRNA levels of genes related to the apoptosis such as Bcl-2 and Bax using Western blot and real-time quantitative PCR (RT-qPCR). As shown in Figure 8, the anti-apoptotic gene Bcl-2 was down-regulated and the pro-apoptotic gene Bax was up-regulated at both 
protein and mRNA levels after the cells were treated with penicitrinine A (Figure 8A-C). The ratio of $\mathrm{Bcl}-2 / \mathrm{Bax}$, which is a key factor regulating apoptosis, was decreased with the increased concentration of penicitrinine A (Figure 8D). These findings suggested that penicitrinine A-induced apoptosis might be involved in the mitochondrion-mediated apoptosis pathway.

A

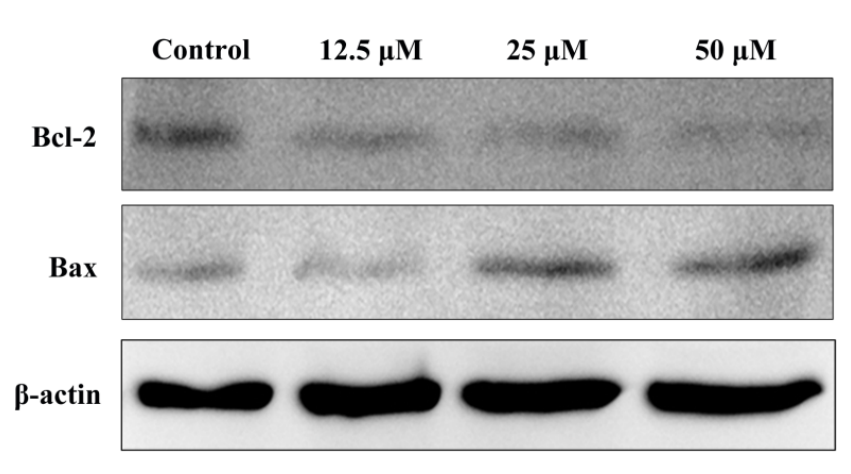

$\mathrm{C}$

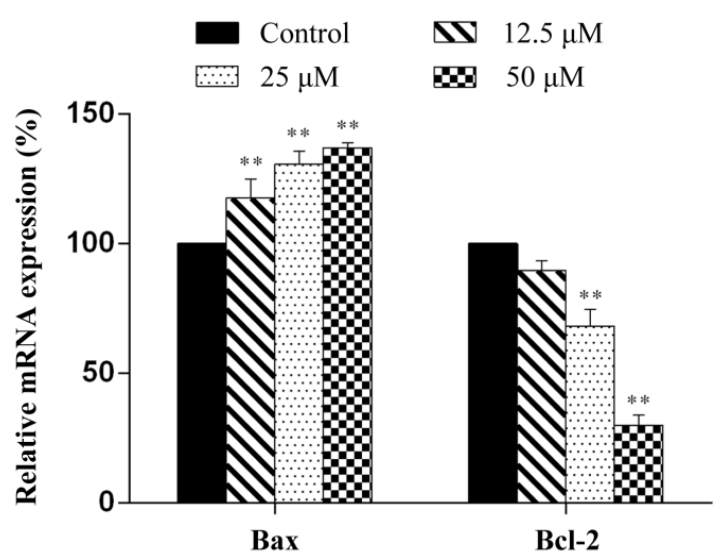

B

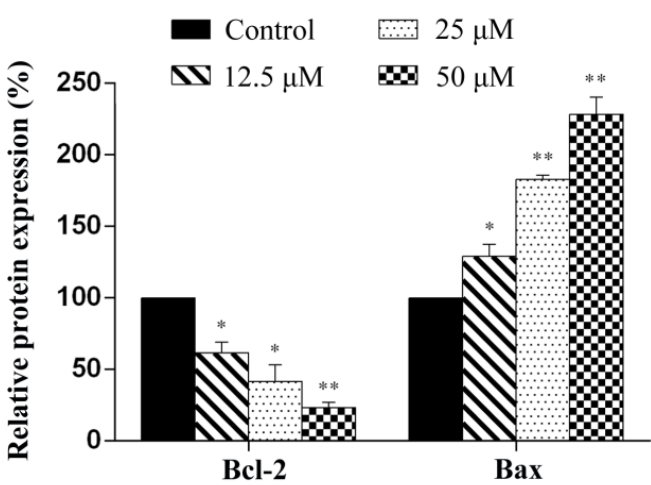

$\mathrm{D}$

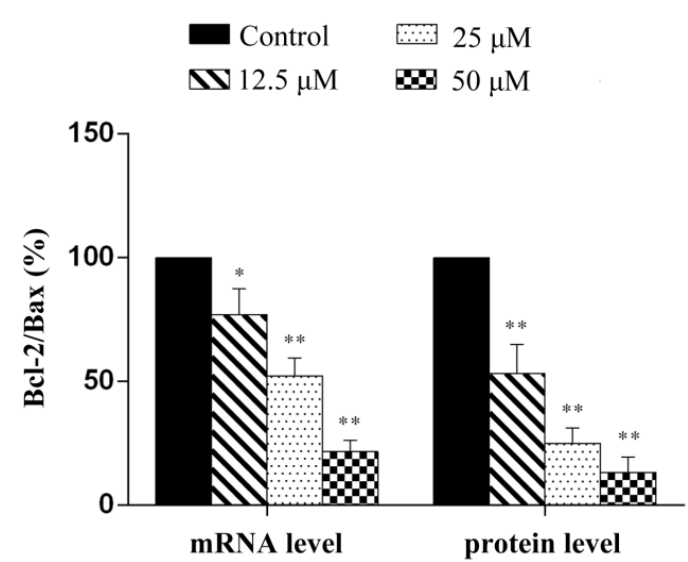

Figure 8. Western blot and RT-qPCR analysis of the apoptosis-associated molecules in A-375 cells. (A) After cells were treated with different concentrations of penicitrinine A for $24 \mathrm{~h}$, western blot analysis was performed using antibodies against Bcl-2, Bax and $\beta$-actin; (B) Densitometric analysis of Bcl-2 and Bax at protein levels; (C) A-375 cells were treated with $0,12.5,25$ and $50 \mu \mathrm{M}$ penicitrinine A for $24 \mathrm{~h}$. The mRNA levels from whole cell lysates were analyzed by RT-qPCR, GAPDH was used as a loading control; (D) Summary of the ratio of Bcl-2 to Bax as demonstrated by histograms. Data are expressed as mean $\pm \operatorname{SEM}(n=3) . * p<0.05, * * p<0.01 v s$. the control group.

\subsection{Penicitrinine A Inhibits the Cell Migration and Invasion in A-375 Cells}

Since malignant melanomas are characterized by frequent metastasis, we further determined the function of penicitrinine A in cell migration and invasion. We first performed a wound healing assay in A-375 cells and observed that the cells treated with penicitrinine A were significantly inhibited to migrate to the wounded area in a dose-dependent manner (Figure 9). 


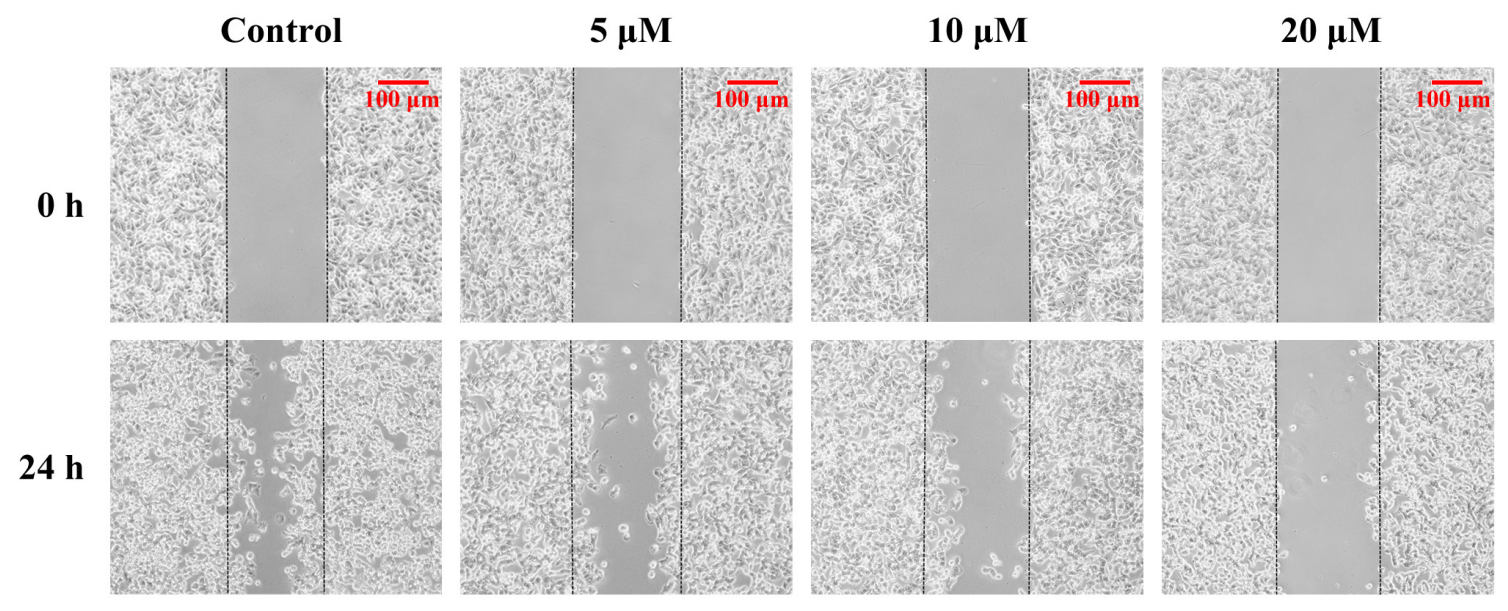

Figure 9. Effects of penicitrinine $A$ on the wound healing migration of A-375 cells. A wound was introduced by scraping confluent cell layers with a pipet tip. A-375 cells were incubated with penicitrinine A $(5,10$ or $20 \mu \mathrm{M})$ for $24 \mathrm{~h}$. Photos of the wounds were taken at 0 and $24 \mathrm{~h}$ under an inverted microscope.

We further performed the trans-well assay to evaluate the inhibitory effect of penicitrinine $\mathrm{A}$ on the invasive features of A-375 cells. The results showed that penicitrinine A suppressed the invasion of A-375 cells across the Matrigel-coated filter in a dose-dependent manner. As shown in Figure 10, the cell invasion was reduced by $40.2 \%, 69.3 \%$ and $81.6 \%$ when treated with penicitrinine $\mathrm{A}$ at doses of 5 , 10 and $20 \mu \mathrm{M}$, compared with the untreated control.

A

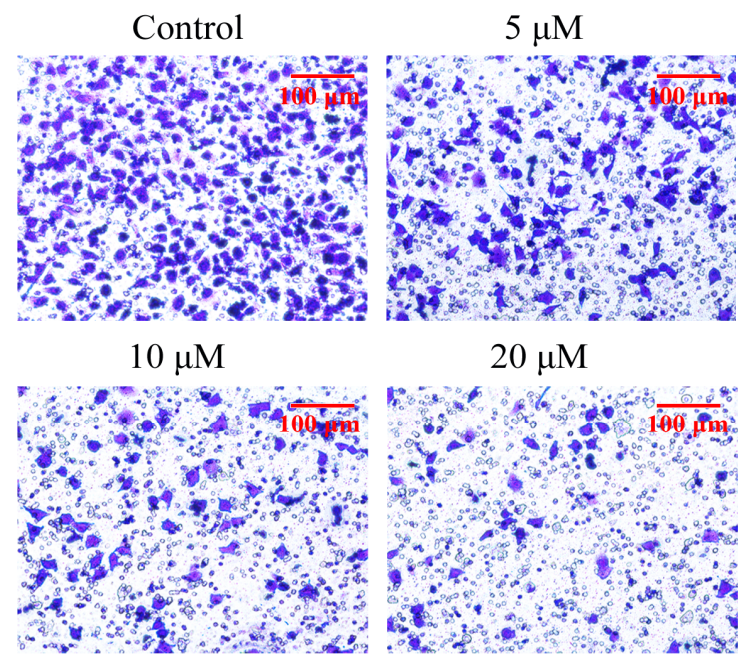

B

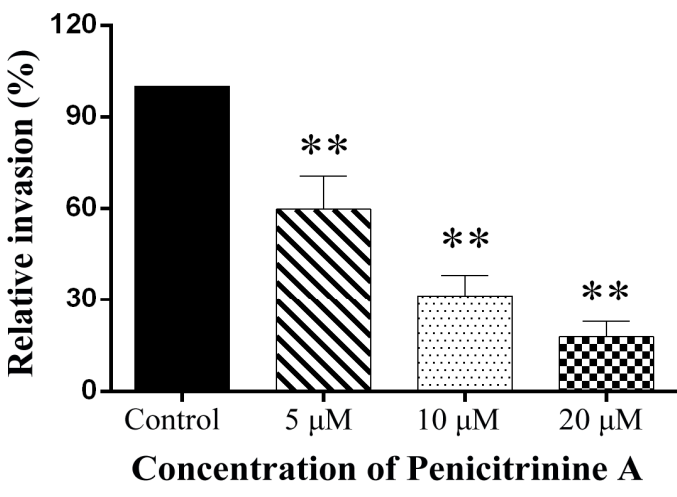

Figure 10. Effect of penicitrinine $A$ on the transwell invasion assay of A-375 cells. (A) A-375 cells incubated with penicitrinine A $(5,10$, or $20 \mu \mathrm{M})$ were plated in the upper chambers of Matrigel-coated transwell insert for $24 \mathrm{~h}$. The lower chamber contained $20 \%$ FBS as a chemoattractant in the medium. After incubated for $24 \mathrm{~h}$, cells were fixed by methanol, stained with crystal violet, and observed under microscope; (B) The invaded A-375 cells were counted in five random fields in each treatment, and data were calculated from three independent experiments. Data are presented as mean $\pm \mathrm{SD}$ of three independent experiments. $* p<0.05, * * p<0.01$ compared with the untreated control. 


\subsection{Penicitrinine A Modulates Metastatic-Related Proteins in A-375 Cells}

To evaluate whether penicitrinine $\mathrm{A}$ is able to suppress the metastatic potential of highly metastatic cancer cells, the modulation of the protein and mRNA expression levels of genes associated with metastasis was examined using western blot analysis and RT-qPCR. The results showed that penicitrinine A treatment leads to the down-regulation of MMP-9 in both protein the mRNA levels, whereas the expression of TIMP-1 was up-regulated in a dose-independent manner, demonstrating that penicitrinine A suppresses cell migration by up-regulating TIMP-1 and down-regulation MMP-9 levels in human melanoma A-375 cell line, as shown in Figure 11.

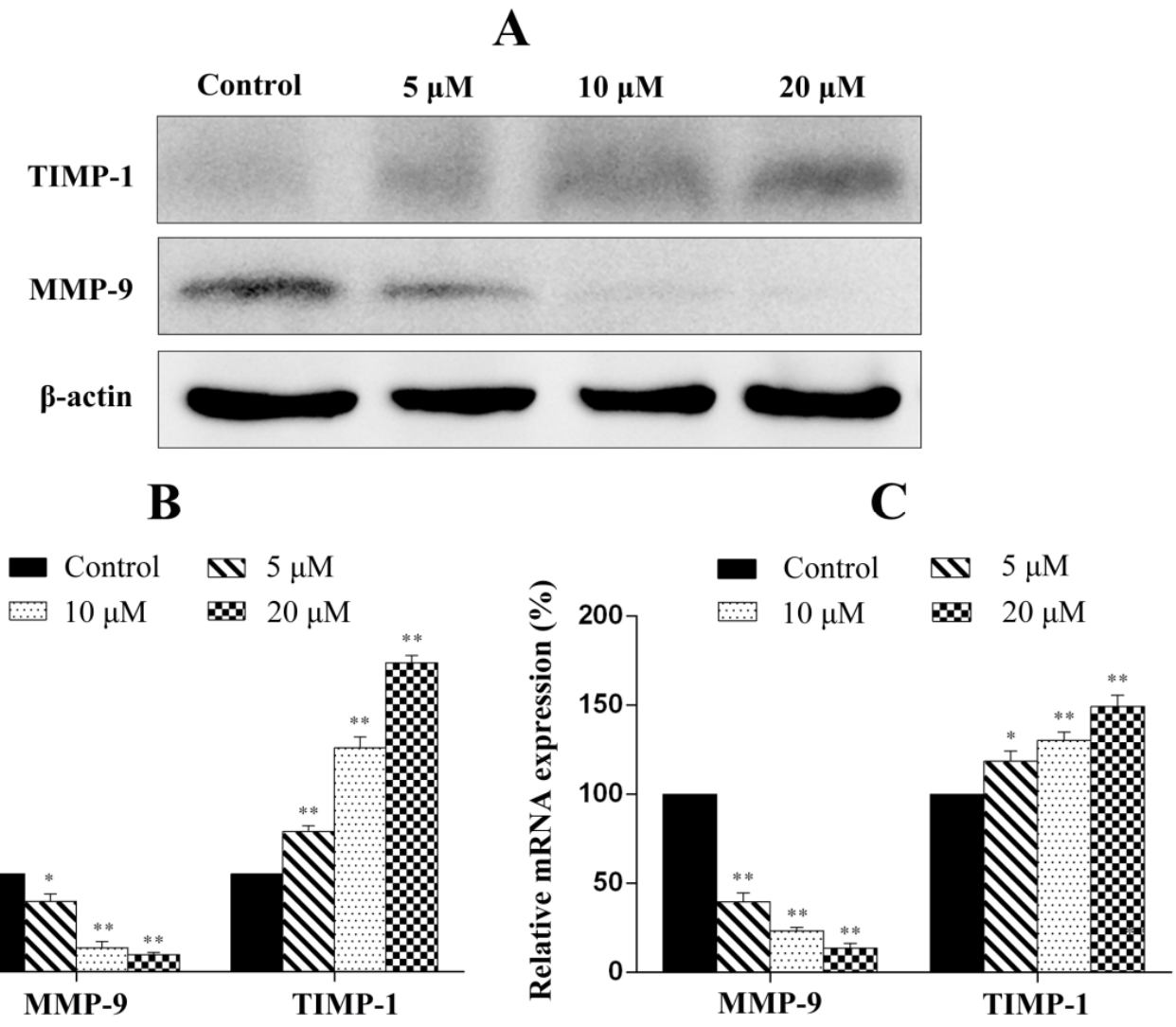

Figure 11. RT-qPCR and western blot analysis of the metastatic-associated molecules in A-375 cells. (A) After cells were treated with different concentration of penicitrinine A for $24 \mathrm{~h}$, western blot analysis was performed using antibodies against TIMP-1, MMP-9 and $\beta$-actin; (B) Densitometric analysis of MMP-9 and TIMP-1 at protein levels; (C) A-375 cells were treated with $0,5,10$ and $20 \mu \mathrm{M}$ penicitrinine A for $24 \mathrm{~h}$. The mRNA level from whole cell lysates was analyzed by RT-qPCR, GAPDH was used as a loading control. Data are expressed as mean $\pm \operatorname{SEM}(n=3) .{ }^{*} p<0.05, * * p<0.01 v s$. the control group.

\subsection{Discussion}

In recent years, the use of marine natural products for cancer prevention and therapy has received a great deal of attention owing to their various health benefits and noticeable lack of toxicity and side effects [23]. Penicitrinine A, a novel alkaloid with a unique spiro skeleton, was isolated and purified from marine-derived fungus $P$. citrinum. Further molecular mechanism study revealed that 
penicitrinine A could induce apoptosis of multiple human tumor types, especially melanoma cancer cell line A-375, under the regulation of Bcl-2 family, and inhibit the metastasis of A-375 through up-regulation of TIMP-1 and down-regulation of MMP-9, suggesting that penicitrinine A might be a potential antitumor agent.

The structure of penicitrinine A was established mainly by NMR and HRESIMS analyses. Moreover, we presumed a plausible biosynthetic pathway of penicitrinine A by Diels-Alder [4 +2$]$ reaction. Until now, penicitrinine $\mathrm{A}$ is the first metabolite biosynthetized from citrinin and tetramic acid derivatives in nature.

Cytotoxic activity is regarded as the first indicator in identifying anticancer drugs [24]. In the previous studies, we evaluated the cytotoxic activities of the metabolites obtained from P. citrinum [19,21,22,25]. Among them, dicitrinone B showed potent anticancer efficacy against multiple human tumor types. Considering penicitrinine A has a similar structural part to dicitrinone B, we, for the first time, detected the effects of penicitrinine A on the growth against human stomach, lung, colon, melanoma, oral epidermoid, liver, nasopharynx, esophagus, breast and lymphoma cancer cell lines. Similar to the results of dicitrinone B, different tumor cell lines had different levels of proliferation inhibition after being treated with penicitrinine A. Most interestingly, the most sensitive cell line was also melanoma A-375 cells. We further studied the anticancer activity of penicitrinine A and the first-line chemotherapy drug 5-Fu on A-375 cells with RTCA assay, the $\mathrm{IC}_{50}$ value for $48 \mathrm{~h}$ under penicitrinine $\mathrm{A}(12.78 \mu \mathrm{M})$ treatment presented slightly lower than dicitrinone $\mathrm{B}(13.38 \mu \mathrm{M})$ and much less than $5-\mathrm{Fu}(65.96 \mu \mathrm{M})$, suggesting that penicitrinine A has stronger cytotoxic activity than dicitrinone B.

Apoptosis is a highly conserved process that plays an important role in the regulation of the cellular activities of eukaryotes and is characterized by chromatin condensation [26,27]. Several studies reported that apoptosis in the A-375 cells presented typical apoptotic morphological changes with cell shrinkage, nuclei blebbing, chromatin condensation, and nuclear fragmentation [28,29]. Our data indicated penicitrinine A induced A-375 cells apoptosis, since cells changed nuclear morphology by chromatin condensation using Hoechst 33258 and AO/EB staining. Annexin V-FITC/PI staining results further confirmed that treatment with penicitrinine A has more remarkable effect in increasing the early and late apoptotic rates than 5-Fu. Apoptotic processes can be divided into two major pathways: the extrinsic pathway and the intrinsic pathway [30,31]. The intrinsic pathway is triggered by a large number of intracellular signals located in the endoplasmic reticulum or mitochondria [32]. One of the most important regulators of the mitochondrion-mediated pathway is the Bcl-2 protein family [33]. Members of this family can either possess pro-apoptotic characteristics, such as Bax, Bak, Bad and Bid, or possess anti-apoptotic characteristics, such as Bcl-2, Bcl-XL, Bcl-W and Mcl-1. Typically, the ratio of Bcl-2 and Bax indicates the threshold sensitivity of cells to the induction of apoptosis via the intrinsic pathway [34]. Our data clearly showed that penicitrinine A treatment resulted in a dose-dependent increase in the level of Bax with a concomitant decrease in Bcl-2 level and finally the decrease of Bcl-2/Bax ratio, demonstrating that penicitrinine A could promote the apoptosis process by changing the expression ratio of Bcl-2/Bax, but the details of the mechanisms need further study.

Malignant melanomas are characterized by a high capacity for metastasis [35]. In the present study, we observed that penicitrinine A could effectively inhibit the potential invasion and migration of A-375 cells by wound healing assay and trans-well assay. Degradation of the extracellular matrix is thought to 
be a key mechanism in tumor metastasis, and the process could be regulated by the expression of MMPs protein families and their specific inhibitor TIMPs [36]. Our results identified that penicitrinine A treatment significantly suppressed the expression of MMP-9 but promoted the expression of its inhibitor TIMP-1, at both transcriptional and translational levels in A-375 cells. Moreover, the increase of metastatic melanoma cells was reported to be associated with enhanced tendency to undergo epithelial-mesenchymal transition (EMT) [37-39]. In fact, we also analyzed several EMT biomarkers such as E-cadherin, N-cadherin and Snaill at transcriptional level, and found penicitrinine A could affect the EMT process by reducing the expression of N-cadherin and Snaill (data not shown). However, the detail mechanism needs further study.

In conclusion, this is the first report that clearly described the structure and the antitumor properties of penicitrinine A, as well as identified its mechanism in a tumor model. Penicitrinine A not only induced cell apoptosis by regulated Bcl-2 and Bax secretion but inhibited cell metastasis through suppressed MMP-9 activity, suggesting that penicitrinine A is a promising chemotherapeutic agent to the treatment of melanoma A-375 cells.

\section{Experimental Section}

\subsection{Isolation of Penicitrinine A}

\subsubsection{General Experimental Procedures}

Optical rotations were obtained from a Shenguang SGW-1 digital polarimeter (Shenguang, Shanghai, China). UV spectra were recorded on a Shimadzu UV-2450 spectrophotometer (Shimadzu, Kyoto, Japan). IR spectra were recorded on a Nicolet Avatar 670 spectrophotometer (Thermo Fisher, Waltham, MA, USA). ${ }^{1} \mathrm{H}-\mathrm{NMR},{ }^{13} \mathrm{C}-\mathrm{NMR}$, DEPT spectra and 2D-NMR were recorded on a BRUKER BIOSPIN AVANCE III spectrometer (Bruker, Karlsruhe, Germany). Using TMS as the internal standard. HRESIMS were obtained by an AGILENT 1200/Q-TOF 6510 LC mass spectrometer (Agilent, Palo Alto, CA, USA). Semipreparative HPLC was performed using an ODS column (ODS-A, $10 \times 250 \mathrm{~mm}$, $5 \mu \mathrm{m})$ (YMC, Tokyo, Japan) at $5 \mathrm{~mL} / \mathrm{min}$.

\subsubsection{Fungal Material}

The fungus $P$. citrinum was isolated from marine sediments collected from Langqi Island, Fujian, China. It was identified according to its morphological characteristics and ITS by Beijing Sunbiotech Co. Ltd (Beijing, China), and preserved in our laboratory at $-80^{\circ} \mathrm{C}$. The producing strain was prepared on Martin medium and stored at $4{ }^{\circ} \mathrm{C}$.

\subsubsection{Fermentation and Extraction}

The fungus was cultured under static conditions at $28^{\circ} \mathrm{C}$ for 30 days in $1000-\mathrm{mL}$ conical flasks containing the liquid medium (400 mL/flask), composed of glucose (10 g/L), maltose (20 g/L), mannitol $(20 \mathrm{~g} / \mathrm{L})$, monosodium glutamate $(10 \mathrm{~g} / \mathrm{L}), \mathrm{KH}_{2} \mathrm{PO}_{4}(0.5 \mathrm{~g} / \mathrm{L}), \mathrm{MgSO}_{4} \cdot 7 \mathrm{H}_{2} \mathrm{O}(0.3 \mathrm{~g} / \mathrm{L})$, yeast extract $(3 \mathrm{~g} / \mathrm{L})$, and seawater. The fermented whole broth $(60 \mathrm{~L})$ was filtered through cheesecloth to 
separate supernatant from mycelia. The former was extracted two times with EtOAc to give an EtOAc solution that was concentrated under reduced pressure to give a crude extract (32.0 g).

\subsubsection{Purification of Penicitrinine A}

The broth extract (32.0 g) was separated into 11 fractions on a Si gel column using a step gradient elution of petroleum ether, $\mathrm{CH}_{2} \mathrm{Cl}_{2}$, and $\mathrm{MeOH}$. Fraction 7 (4.2 g) eluted with $\mathrm{CH}_{2} \mathrm{Cl}_{2}: \mathrm{MeOH}=100: 1$ was further purified on a Si gel column using a step gradient elution. Subfraction 7-6 (400 mg) was purified by semipreparative HPLC (75\% MeCN containing $0.1 \%$ TFA) to yield compound 1 (97.9 mg).

\subsubsection{Spectral Data}

Penicitrinine A: yellow oil $\left(\mathrm{CHCl}_{3}\right) ;[\alpha]_{\mathrm{D}}^{20}+74.0^{\circ}\left(c \quad 0.20, \mathrm{CHCl}_{3}\right)$; UV $(\mathrm{MeOH}) \lambda \max (\log \varepsilon) 252$ (2.81), 287 (2.94) nm; IR (KBr) $v_{\max }$ 3440, 2970, 2929, 2856, 1724, 1659, 1601, 1462, 1377, 1343, 1123, $1046 \mathrm{~cm}^{-1}$; ${ }^{1} \mathrm{H}$ - and ${ }^{13} \mathrm{C}-\mathrm{NMR}$ data (see Table 1); HRESIMS $m / z 484.2711[\mathrm{M}-\mathrm{H}]^{-}$(calcd. for $\left.\mathrm{C}_{28} \mathrm{H}_{38} \mathrm{NO}_{6}, 484.2705\right)$.

\subsection{Cell Culture and Treatment}

Malignant melanoma A-375 cells were obtained from Shanghai Cell Resource Center (Shanghai, China) and were cultured in DMEM (Hyclone, Thermo Scientific, Beijing, China) medium. The medium was supplemented with 10\% fetal bovine serum (Hyclone) and the cells were incubated in a humidifier with $5 \% \mathrm{CO}_{2}$ at $37^{\circ} \mathrm{C}$. At various concentrations after the treatment, the cells were processed for the analyses of cell cytotoxicity, morphology changes, apoptosis and motility.

\subsection{WST-1 Cell Proliferation Assay}

Cytotoxic activity was evaluated by the WST-1 cell proliferation assay kit (Roche, Indianapolis, IN, USA). Briefly, cells were cultured in 96-well plate, and treated with gradient concentrations of penicitrinine A. After $48 \mathrm{~h}$, one-tenth volume WST-1 solution was added. After cells were incubated at $37{ }^{\circ} \mathrm{C}$ for $4 \mathrm{~h}$, the absorbance at $450 \mathrm{~nm}$ was measured.

\subsection{RTCA Cytotoxicity Assay}

Cell proliferation was performed using the DP version of the xCELLigence real time cell analyzer RTCA (ACEA, San Diego, CA, USA), which records changes in impedance (reported as a cell index-CI) over a prolonged time course in a noninvasive system. Briefly, the background impedance of RTCA DP E-Plates 16 (ACEA, SanDiego, CA, USA) was performed using the standard protocol provided in the software with $50 \mu \mathrm{L}$ of media. $5 \times 10^{3}$ A-375 cells were seeded with $100 \mu \mathrm{L}$ of DMEM and left to equilibrate at room temperature for $30 \mathrm{~min}$. Cells were allowed to grow for $24 \mathrm{~h}$ before adding penicitrinine $\mathrm{A}$ or 5-Fu to the cultures at the indicated concentrations in duplicate. The $\mathrm{CI}$ of the proliferating cells was recorded and expressed as mean of CI normalized to the CI recorded at the time of A-375 cells treatment compared to untreated cells. 


\subsection{Morphological Analysis}

\subsubsection{Hoechst 33258 Staining}

Hoechst labeling of cells was used to detect apoptotic nuclei by evaluation of nuclear morphology. Cells $\left(1 \times 10^{5}\right.$ cells/well $)$ were plated in six-well plates then treated with gradient concentrations of penicitrinine A for $24 \mathrm{~h}$. After incubation, the medium was removed and cells were fixed in a solution of methanol and acetic acid with 3:1 for $10 \mathrm{~min}$ at room temperature. To assess specific apoptosis, Hoechst $33258(10 \mu \mathrm{g} / \mathrm{mL})$ (Sigma, St. Louis, MO, USA) was added to each well and further incubated at room temperature for $15 \mathrm{~min}$ in the dark. After washed with PBS twice, the cells were observed under an Olympus fluorescence microscope (Olympus America Inc., Center Valley, PA, USA).

\subsubsection{AO/EB Staining}

A-375 cells were seeded in six-well plates with different concentrations of penicitrinine A $(12.5,25$ and $50 \mu \mathrm{M}$ ) at $1 \times 10^{5}$ cells/well and incubated at $37^{\circ} \mathrm{C}$ under $5 \%$ atmospheric $\mathrm{CO}_{2}$ concentration for $24 \mathrm{~h}$. AO/EB solution was prepared at $100 \mu \mathrm{g} / \mathrm{mL}$ of each reagent. Cells were harvested and stained with $100 \mu \mathrm{L}$ of AO/EB solution for $15 \mathrm{~min}$, then washed twice with PBS and observed under an Olympus fluorescence microscope (Olympus America Inc., Center Valley, PA, USA). Green color indicated live cells, whereas cells with orange and red color were apoptotic and necrotic cells, respectively.

\subsection{Flow Cytometry Analysis}

Apoptosis in A-375 cells was measured by using the Annexin V FLUOS staining Kit (Roche, Indianapolis, IN, USA). Briefly, cells were exposed to different concentrations of penicitrinine A in six-well plates, were washed twice with PBS solution and then resuspended at a concentration of $1 \times 10^{6}$ cells $/ \mathrm{mL}$ in binding buffer. Subsequently, $1000 \mu \mathrm{L}$ of the cell suspension was mixed with $20 \mu \mathrm{L}$ of Annexin V-Flous and $20 \mu \mathrm{L}$ of PI. After incubated at room temperature for $15 \mathrm{~min}$, apoptotic cells were determined using a FACScan (Beckman Coulter, Brea, CA, USA).

\subsection{Wound Healing Assay}

To assess the motility of cells, a wound healing assay was performed [40]. A-375 cells $\left(1 \times 10^{6}\right.$ cells $\left./ \mathrm{mL}\right)$ were seeded in six-well plates. After $24 \mathrm{~h}$, the center of the cell monolayers was scraped with a sterile micropipette tip to create a straight gap of constant width. Then, each well was washed with PBS, and A-375 cells were exposed to various concentrations of penicitrinine A $(5,10$ or $20 \mu \mathrm{M})$. Wound closure was photographed at $0 \mathrm{~h}$ and $24 \mathrm{~h}$ with an inverted microscope (Nikon, Tokyo, Japan).

\subsection{Trans-Well Assay}

Tumor cell invasion were performed in trans-well chambers (Millipore, Billerica, MA, USA) according to the method reported previously [41], with some modifications. The upper trans-well chambers were coated with Matrigel (BD Biosciences, Franklin Lakes, NJ, USA), A-375 cells $\left(6 \times 10^{5}\right.$ cells/well $)$ and 5,10 or $20 \mu \mathrm{M}$ of penicitrinine A were suspended in DMEM $(100 \mu \mathrm{L}$, serum 
free), placed in the chambers, and the medium of the lower plates also contained $20 \%$ fetal bovine serum as a chemoattractant incubated. The invaded cells on the lower chamber were fixed with methanol and stained with $5 \%$ crystal violet. Then, the cells on the upper surface of the filter were completely wiped away with a cotton swab and photographed under a microscope (Nikon, Tokyo, Japan).

\subsection{Real-Time Quantitative PCR}

For RT-qPCR, total RNA from control as well as cells treated with gradient concentrations of penicitrinine A was extracted using TRIzol reagent (Life Technologies, Carlsbad, CA, USA), according to the manufacturer's protocol. cDNAs were synthesized using the PrimeScript ${ }^{\mathrm{TM}}$ RT reagent kit (Takara, Otsu, Shiga, Japan). Quantitative PCR was performed using the ABI Step one plus System with miScript SYBR Green PCR Kit (QIAGEN, Hilden, Germany) and primers were listed in Table 3.

Table 3. Primers for the genes used in RT-qPCR test.

\begin{tabular}{|c|c|c|}
\hline Gene & & Sequences \\
\hline \multirow{2}{*}{ Bcl-2 } & forward & 5'-CGACTTTGCAGAGATGTCCA-3' \\
\hline & reverse & 5'-ATGCCGGTTCAGGTACTCAG-3' \\
\hline \multirow{2}{*}{ Bax } & forward & 5'-CCTTTTCTACTTTGCCAGCAAAC-3' \\
\hline & reverse & 5'-GAGGCCGTCCCAACCAC-3' \\
\hline \multirow{2}{*}{ MMP-9 } & forward & 5'-CCTGGAGACCTGAGAAC-3' \\
\hline & reverse & 5'-CAGGGACAGTTGCTTCT-3' \\
\hline \multirow{2}{*}{ TIMP-1 } & forward & 5'-ACTCTTGCACATCACTACCT-3' \\
\hline & reverse & 5'-AAACACTGTGCATTCCTC-3' \\
\hline \multirow{2}{*}{ GAPDH } & forward & 5'-GAAGGTGAAGGTCGGAGTC-3' \\
\hline & reverse & 5'-GAAGATGGTGATGGGATTTC-3' \\
\hline
\end{tabular}

The mRNA expression levels were calculated by the $2^{-\Delta \Delta \mathrm{CT}}$ method and expressed in relative quantification units. Each reaction was amplified in triplicate and relative mRNA levels were normalized to those of GAPDH.

\subsection{Western Blot}

A-375 cells were plated in six-well plates at a density of $1 \times 10^{6}$ cells per well and incubated with various concentrations of penicitrinine A for $24 \mathrm{~h}$. The cells were collected, lysed in RIPA buffer. Total proteins were separated by $12 \%$ SDS-PAGE and then transferred to the NC membrane. The membranes were blocked with 5\% (w/v) nonfat dry milk in PBST for one hour and changed to an appropriate dilution of specific primary antibodies against Bcl-2 (1:1000, cell signaling technology), Bax (1:1000, cell signaling technology), MMP-9 (1:1000, cell signaling technology), TIMP-1 (1:1000, cell signaling technology) and $\beta$-actin $(1: 1000$, cell signaling technology) in milk overnight at $4{ }^{\circ} \mathrm{C}$. The secondary antibodies were peroxidase-conjugated anti-rabbit IgG (1:5000). Signals were detected by an electrochemiluminescence (ECL) reagent using Image Station 4000Mm digital darkroom system (Kodak, St. Rochester, NY, USA). 


\title{
3.11. Statistical Analysis
}

The values were presented as means \pm SD. Statistical analyses were performed using student's $t$-test. $p<0.05$ was considered statistically significant for all tests.

\section{Conclusions}

This study investigated a new compound penicitrinine A isolated and identified from marine fungus P. citrinum. We found that penicitrinine A has cytotoxic activity on a wide range of tumor cells, including A-375 cells. Further studies have shown that penicitrinine A induced A-375 cells apoptosis by regulating the Bcl-2 family proteins, and significantly suppressed the migration of A-375 cells through regulating the expression of MMP-9 and its specific inhibitor TIMP-1. These findings demonstrated the biological activity of penicitrinine $\mathrm{A}$ in in vitro models of cancer apoptosis and metastasis, and showed that penicitrinine $\mathrm{A}$, which has a unique chemical structure, could serve as a lead compound for rational drug design and for future development of anticancer agents.

\section{Acknowledgments}

This research was supported by the Chinese National Natural Science Fund (21102015 and 31201034), the Joint Project of Ministry of Sanitation and Ministry of Education in Fujian Province (WKJ-FJ-14), Natural Science Foundation of Fujian Province (2014J01301 and 2012J05138), the Key Project of Department of Science and Technology in Fujian Province (2012Y0017), and the National Clinical Key Specialty Construction Program.

\section{Author Contributions}

Q.Y.L. and L.C. conceived and designed the research. L.C., Q.Y.L. and Q.H.Z. supervised the research. T.Z., Y.Y.Z. and M.W.G. performed the cell biology experiments. T.Z. and Q.W.X. purified the compound. Q.Y.L., T.Z. and L.C. analyzed the data and wrote the paper. Q.Q.Z. and M.G.Y. reviewed and edited the manuscript.

\section{Conflicts of Interest}

The authors declare no conflict of interest.

\begin{abstract}
Abbreviations
HPLC, high performance liquid chromatography; NMR, nuclear magnetic resonance; HRESIMS, high resolution electrospray ionization mass spectroscopy; DEPT, distortionless enhancement by polarization transfer; HMBC, heteronuclear multiple bond connectivity; HMQC, heteronuclear multiple quantum connectivity; 5-Fu, 5-fluorouracil; AO/EB, acridine orange/ethidium bromide; MMP-9, matrix metallopeptidase 9; TIMP-1, metallopeptidase inhibitor 1; RTCA, real time cell analyzer; CTLA-4, cytotoxic T-lymphocyte-associated protein 4; PD-1, programmed cell death 1; COSY, (homonuclear chemical shift) correlation spectroscopy; NOESY, nuclear overhauser enhancement spectroscopy; GAPDH, glyceraldehyde-3-phosphate dehydrogenase; FBS, fetal bovine serum;
\end{abstract}


PI, propidium iodide; TMS, tetramethylsilane; DMEM, dulbecco's modified eagle's medium; PBS, phosphate buffered solution.

\section{References}

1. Landis, S.H.; Murray, T.; Bolden, S.; Wingo, P.A. Cancer statistics, 1999. CA-Cancer J. Clin. 1999, 49, 8-31.

2. Rigel, D.S. Epidemiology of melanoma. Semin. Cutan. Med. Surg. 2010, 29, 204-209.

3. Ott, P.A.; Hodi, F.S.; Robert, C. CTLA-4 and PD-1/PD-L1 blockade: New immunotherapeutic modalities with durable clinical benefit in melanoma patients. Clin. Cancer Res. 2013, 19, 5300-5309.

4. Luke, J.J.; Schwartz, G.K. Chemotherapy in the management of advanced cutaneous malignant melanoma. Clin. Dermatol. 2013, 31, 290-297.

5. Tao, L.-Y.; Zhang, J.-Y.; Liang, Y.-J.; Chen, L.-M.; Zheng, L.-S.; Wang, F.; Mi, Y.-J.; She, Z.-G.; To, K.K.W.; Lin, Y.-C. Anticancer effect and structure-activity analysis of marine products isolated from metabolites of mangrove fungi in the South China Sea. Mar. Drugs 2010, 8, 1094-1105.

6. Kinghorn, A.D.; Carcache de Blanco, E.J.; Chai, H.B.; Orjala, J.; Farnsworth, N.R.; Soejarto, D.D.; Oberlies, N.H.; Wani, M.C.; Kroll, D.J.; Pearce, C.J.; et al. Discovery of anticancer agents of diverse natural origin. Pure Appl. Chem. 2009, 81, 1051-1063.

7. Xiong, Z.-Q.; Wang, J.-F.; Hao, Y.-Y.; Wang, Y. Recent advances in the discovery and development of marine microbial natural products. Mar. Drugs 2013, 11, 700-717.

8. Waters, A.L.; Hill, R.T.; Place, A.R.; Hamann, M.T. The expanding role of marine microbes in pharmaceutical development. Curr. Opin. Biotechnol. 2010, 21, 780-786.

9. Mitchell, S.S.; Nicholson, B.; Teisan, S.; Lam, K.S.; Potts, B.C. Aureoverticillactam, a novel 22-atom macrocyclic lactam from the marine actinomycete Streptomyces aureoverticillatus. J. Nat. Prod. 2004, 67, 1400-1402.

10. Blunt, J.W.; Copp, B.R.; Munro, M.H.; Northcote, P.T.; Prinsep, M.R. Marine natural products. Nat. Prod. Rep. 2006, 23, 26-78.

11. Williams, P.G. Panning for chemical gold: Marine bacteria as a source of new therapeutics. Trends Biotechnol. 2009, 27, 45-52.

12. Blunt, J.W.; Copp, B.R.; Hu, W.P.; Munro, M.H.; Northcote, P.T.; Prinsep, M.R. Marine natural products. Nat. Prod. Rep. 2009, 26, 170-244.

13. Lavrard, H.; Salvetti, B; Mathieu, V.; Rodriguez, F.; Kiss, R.; Delfourne, E. Synthesis and in vitro antiproliferative activity of amido and amino analogues of the marine alkaloid isogranulatimide. Chem. Med. Chem. 2015, 10, 607-609.

14. Goncalves, A.M.; de Lima, A.B.; da Silva Barbosa, M.C.; de Camargos, L.F.; de Oliveira, J.T.; de Souza Barbosa, C.; Villar, J.A.; Costa, A.C.; da Silva, I.V.G.; Silva, L.M.; et al. Synthesis and biological evaluation of novel 3-alkylpyridine marine alkaloid analogs with promising anticancer activity. Mar. Drugs 2014, 12, 4361-4378. 
15. Demchuk, D.V.; Samet, A.V.; Chernysheva, N.B.; Ushkarov, V.I.; Stashina, G.A.; Konyushkin, L.D.; Raihstat, M.M.; Firgang, S.I.; Philchenkov, A.A.; Zavelevich, M.P.; et al. Synthesis and antiproliferative activity of conformationally restricted 1,2,3-triazole analogues of combretastatins in the seaurchin embryo model and agaist human cancel cell lines. Bioog. Med. Chem. 2014, 22, 738-755.

16. Carbone, A.; Parrino, B.; Barraja, P.; Spanò, V.; Cirrincione, G.; Diana, P.; Maier, A.; Kelter, G.; Fiebig, H.-H. Synthesis and antiproliferative activity of 2,5-bis(3'-Indolyl)pyrroles, analogues of the marine alkaloid Nortopsentin. Mar. Drugs 2013, 11, 643-654.

17. Carbone, A.; Pennati, M.; Parrino, B.; Lopergolo, A.; Barraja, P.; Montalbano, A.; Spanò, V.; Sbarra, S.; Doldi, V.; de Cesare, M.; et al. Novel 1H-pyrrolo[2,3-b]pyridine derivatives nortopsentin analogues: Synthesis and antitumor activity in peritoneal mesothelioma experimental models. J. Med. Chem. 2013, 56, 7060-7072.

18. Parrino, B.; Carbone, A.; di Vita, G.; Ciancimino, C.; Attanzio, A.; Spanò, V.; Montalbano, A.; Barraja, P.; Tesoriere, L.; Livrea, M.A.; et al. 3-[4-(1H-Indol-3-yl)-1,3-thiazol-2-yl]-1H-pyrrolo[2,3-b] pyridines, nortopsentin analogues with antiproliferative activity. Mar. Drugs 2015, 13, 1901-1924.

19. Chen, L.; Liu, W.; Hu, X.; Huang, K.; Wu, J.-L.; Zhang, Q.-Q. Citrinin derivatives from the marine-derived fungus Penicillium citrinum. Chem. Pharm. Bull. 2011, 59, 515-517.

20. Lin, Z.-J.; Lu, Z.-Y.; Zhu, T.-J.; Fang, Y.-C.; Gu, Q.-Q.; Zhu, W.-M. Penicillenols from Penicillium sp. GQ-7, an endophytic fungus associated with Aegiceras corniculatum. Chem. Pharm. Bull. 2008, 56, 217-221.

21. Chen, L.; Liu, W.; Huang, K.; Hu, X.; Fang, Z.-X.; Wu, J.-L.; Zhang, Q.-Q. Penicitrinols F-I, new citrinin derivatives from the marine-derived fungus Penicillium citrinum. Heterocycles 2011, 83, 1853-1858.

22. Chen, L.; Huang, K.; Zhong, P.; Hu, X.; Fang, Z.-X.; Wu, J.-L.; Zhang, Q.-Q. Tumonoic acids K and $\mathrm{L}$, novel metabolites from the marine-derived fungus Penicillium citrinum. Heterocycles 2012 , 85, 413-419.

23. Demain, A.L.; Vaishnav, P. Natural products for cancer chemotherapy. Microb. Biotechnol. 2011, 4, 687-699.

24. Essack, M.; Bajic, V.B.; Archer, J.A. Recently confirmed apoptosis-inducing lead compounds isolated from marine sponge of potential relevance in cancer treatment. Mar. Drugs 2011, 9, 1580-1606.

25. Chen, L.; Gong, M.-W.; Peng, Z.-F.; Zhou, T.; Ying, M.-G.; Zheng, Q.-H.; Liu, Q.-Y.; Zhang, Q.-Q. The marine fungal metabolite, dicitrinone B, induces A375 cell apoptosis through the ROS-related caspase pathway. Mar. Drugs 2014, 12, 1939-1958.

26. Elmore, S. Apoptosis: A review of programmed cell death. Toxicol. Pathol. 2007, 35, 495-516.

27. Zhou, X.; Zhao, A.; Goping, G.; Hirszel, P. Gliotoxin-induced cytotoxicity proceeds via apoptosis and is mediated by caspases and reactive oxygen species in LLC-PK1 cells. Toxicol. Sci. 2000, 54, 194-202.

28. Nguyen, V.T.; Lee, J.S.; Qian, Z.J.; Li, Y.X.; Kim, K.N.; Heo, S.J.; Jeon, Y.J.; Park, W.S.; Choi, I.W.; Je, J.Y.; et al. Gliotoxin isolated from marine fungus Aspergillus sp. induces apoptosis of human cervical cancer and chondrosarcoma cells. Mar. Drugs 2014, 12, 69-87. 
29. Pellizzari Tregno, F.; Sau, A.; Pezzola, S.; Geroni, C.; Lapenta, C.; Spada, M.; Filomeni, G.; Bonanno, E.; Federici, G.; Caccuri, A.M. In vitro and in vivo efficacy of 6-(7-nitro-2,1, 3-benzoxadiazol-4-ylthio)hexanol (NBDHEX) on human melanoma. Eur. J. Cancer 2009, 45, 2606-2617.

30. Li, H.-H.; Su, J.-H.; Chiu, C.-C.; Lin, J.-J.; Yang, Z.-Y.; Hwang, W.-I.; Chen, Y.-K.; Lo, Y.-H.; $\mathrm{Wu}$, Y.-J. Proteomic investigation of the sinulariolide-treated melanoma cells A375: Effects on the cell apoptosis through mitochondrial-related pathway and activation of caspase cascade. Mar. Drugs 2013, 11, 2625-2642.

31. Denicourt, C.; Dowdy, S.F. Medicine. Targeting apoptotic pathways in cancer cells. Science 2004, 305, 1411-1413.

32. Liao, C.-T.; Chang, J.-T.; Wang, H.-M.; Ng, S.-H.; Hsueh, C.; Lee, L.-Y.; Lin, C.-H.; Chen, I.-H.; Huang, S.-F.; Cheng, A.-J.; et al. Analysis of risk factors of predictive local tumor control in oral cavity cancer. Ann. Surg. Oncol. 2008, 15, 915-922.

33. Cory, S.; Adams, J.M. The Bcl-2 family: Regulators of the cellular life-or-death switch. Nat. Rev. Cancer 2002, 2, 647-656.

34. Danial, N.N.; Korsmeyer, S.J. Cell death: Critical control points. Cell 2004, 116, 205-219.

35. Ahonen, M.; Baker, A.H.; Kahari, V.M. Adenovirus-mediated gene delivery of tissue inhibitor of metalloproteinases-3 inhibits invasion and induces apoptosis in melanoma cells. Cancer Res. 1998, 58, 2310-2315.

36. Buettner, R.; Mesa, T.; Vultur, A.; Lee, F.; Jove, R. Inhibition of Src family kinases with dasatinib blocks migration and invasion of human melanoma cells. Mol. Cancer Res. 2008, 6, 1766-1774.

37. Lin, K.; Baritaki, S.; Militello, L.; Malaponte, G.; Bevelacqua, Y.; Bonavida, B. The role of B-RAF mutations in melanoma and the induction of EMT via dysregulation of the NF-kappaB /Snail/RKIP/PTEN circuit. Genes Cancer 2010, 1, 409-420.

38. Vaid, M.; Singh, T.; Katiyar, S.K. Grape seed proanthocyanidins inhibit melanoma cell invasiveness by reduction of PGE2 synthesis and reversal of epithelial-to-mesenchymal transition. PLoS ONE 2011, 6, e21539.

39. Caramel, J.; Papadogeorgakis, E.; Hill, L.; Browne, G.J.; Richard, G.; Wierinckx, A.; Saldanha, G.; Osborne, J.; Hutchinson, P.; Tse, G.; et al. A switch in the expression of embryonic EMT-inducers drives the development of malignant melanoma. Cancer Cell 2013, 24, 466-480.

40. Ma, L.; Yan, H.; Zhou, Q. AG1478 inhibits the migration and invasion of cisplatin-resistant human lung adenocarcinoma cells via the cell cycle regulation by matrix metalloproteinase-9. Oncol. Lett. 2014, 8, 921-927.

41. Zhang, Q.-Y.; Li, R.; Zeng, G.-F.; Liu, B.; Liu, J.; Shu, Y.; Liu, Z.-K.; Qiu, Z.-D.; Wang, D.-J.; Miao, H.-L.; et al. Dihydromyricetin inhibits migration and invasion of hepatoma cells through regulation of MMP-9 expression. World J. Gastroenterol. 2014, 20, 10082-10093.

(C) 2015 by the authors; licensee MDPI, Basel, Switzerland. This article is an open access article distributed under the terms and conditions of the Creative Commons Attribution license (http://creativecommons.org/licenses/by/4.0/). 